\title{
Pathologies and kitsch in the workplace - theoretical perspective
}

\author{
Stanisław Ciupka ${ }^{1}$, \\ ${ }^{1}$ Bielsko-Biała School of Finance nad Law \\ Tańskiego 5, Bielsko-Biała - Poland
}

\begin{abstract}
In this article we would like to touch upon the problem of reprehensible practices, pathologies that are present in many economic organizations today. We would like to consider how much unethical behavior should be largely attributed to employees, and how much it is associated with external cultural, organizational and situational factors. With this perspective, the author wants to associate pathologies in the workplace with the rich in associations, synonymous with the word kitsch, which can also be applied to economic and business issues. It is worth emphasizing that kitsch and pathology seem to permeate, and maybe even one of them can result from another. This is a paradox that the author wants to address in this article. The proper tracking of the activities of organizations by their management is the basic form of preventing pathologies in the organization. It is also associated with a significant impact on the economy, because the effectiveness of work is closely related to the problems of anxiety or embarrassment in the workplace. Some researchers may conclude that kitsch, pathology and frustration that leads to professional burnout can often be related to workaholism or even law violations in specific companies. This article is based on the method of critical analysis of literature and the method of deduction in observing behavior in organizations.
\end{abstract}

Index Terms - Kitsch, pathology, corruption, mobbing, work addiction, enterprise

\section{INTRODUCTION}

We encounter this word very often in modern times. We recall it not only in issues related to art, but also in the context of multiple phenomena of contemporary culture (Żuchowska 2013, p. 131-151). Kitsch is a colloquial and highly valued term, which at the same time is not easy to include in the system of philosophical, business and economic discourse, and is also very annoying in everyday life. However, it has now become a universal concept, but in an attempt to clarify its content, it turns out to be an extremely ambiguous concept. A word that cannot be unambiguously defined, which is as if present on the border of language. Kitsch, apart from being an extremely difficult phenomenon to define unambiguously, is also primarily mono subjective. Even at the end of the nineteenth century, the term

ASEJ - Scientific Journal of Bielsko-Biala School of Finance and Law

Volume 24, No 1 (2020), 5 pages

DOI: $10.5604 / 01.3001 .0014 .1347$

Received: 06 April 2020; Accepted: 10 April 2020 referred mainly to the field of painting, today it has extended to virtually all areas of life (Piątkowski 2008, p. 12-13; Beylin 1975 , p. 180). The reality that is hidden under this notion has become;

"[...] one of the channels of communication, it directs individual and collective axiologies, emotions, attitudes, behaviors. The transformation of the phenomenon in various fields of human activity has caused that today the essence of kitsch has become not only devaluation, but above all disintegration and diehieratization of aesthetic, ethical and cognitive values. Kitsch is not only a <beautiful effect $>$, exaggeration, rubbish, <easy spiritual experience>, not to say primitive, it is not only pop culture, stereotype, template, seriality, sentimentalism, etc., but kitsch is also a $<$ therapy of complexes $>$ - individual and collective". (Kudra, Szkudlarek 2016, p. 9).

The above mentioned synonyms of the word kitsch, as well as the text quoted above, allow us to use this concept also at the level of economic and business considerations, and to track the correct functioning of enterprises and rugging unwanted pathological symptoms in them.

\section{SELECTED ISSUES OF PATHOLOGY IN THE WORKPLACE}

Among researchers of issues of unethical behaviours in the organisation there is a still unresolved plant, whether the sources of unethical behaviour in enterprises should be sought, as it is conventionally said, in rotten apples, with employees in mind, or in the hypothesis of a bad barrel, taking into account external organisational, cultural and situational factors (Wziątek-Staśko 2016, p. 60; Macko 2009, p. 9). Without entering into this discussion, which has been going on for many years in detail, we would like to draw attention to some very disturbing practices, which unfortunately are strongly rooted in the life and activity of many companies. In the literature on the subject very often the phenomenon of corruption is cited as one of the undesirable dysfunctions in the activity of organisations. It is not easy to define it, because it is an extremely complex, multi-faceted phenomenon, it occurs in many forms and forms.

Regular research paper: Published 30 April 2020

Corresponding author's e-mail: stanislaw.ciupka@op.pl

Copyright $(\mathbb{C} 2018$ This is an open access article distributed under the Creative Commons Attribution CC-BY-NC 4.0 License. 
It is commonly described as:

"[...] falsification of a condition perceived as perfect and ethically good. The very term $<$ corruption $>$ (Latin corrupio $=$ barriers, corruption) has clearly pejorative connotations, indicating covert deviations from the established legal order and ethical standards of conduct. In a narrower sense, corruption is the illegal acceptance of financial benefits in exchange for performing an official act or violating the law (Wziątek-Staśko 2016, p. 61).

The phenomenon of corruption in a company causes many additional, undesirable costs, lowers employee motivation, weakens the good name of the company, deteriorates business relations with partners, violates the sense of organizational trust (Grudzewski, Hejduk, Wańtuchowicz 2009, p. 137; 139). Referring to Transparency International's global report from 2015, which examines countries in terms of the extent of corruption, the most corrupt countries in the world are North Korea, Sudan, Afghanistan. Poland was ranked 35th in this table. Also research from 2016 carried out by Ernest \&Young's Economic Abuse Surveys showed that as much as $61 \%$ of respondents from high growth markets ( Poland classified here) are convinced that fraud and corruption are very widespread. It is worth referring at this point to statement Dylus, who writes:

"Many researchers indeed stand on the position of supracultural corruption, stating that it has accompanied mankind since the dawn of history, or more precisely - from the time when power was formed to modern times, and that it can be found practically everywhere, regardless of the latitude and nature of the culture of a given community, they come to the conclusion that other, extra-cultural elements in whole or above all condition its flourishing [...] From a sociological point of view, corruption $<$ develops and stabilizes as a by-product of the malfunctioning of basic social structures". (Dylus 2006, p. 107; Jarosz 2004, p. 41-73; Makowski 2008, p. 107-120).

Among Polish respondents, as much as $46 \%$ admitted that the phenomenon of corruption, offering gifts, cash, free entertainment are justified if they bring profits to the company and especially if they ensure its survival in the market. It is an unbelievable fact that there is a conviction among Polish managers / $25 \%$ of respondents / that they are ready to give gifts, cash in order to maintain good business relations with a partner. As many as $37 \%$ of Polish respondents note that various types of irregularities in financial statements, reporting on good results at all costs and additionally a non-negligible trend in this respect, are a frequent phenomenon, as $32 \%$ of Polish respondents believe that these practices can be justified if, for example, they allow to survive the slowdown in economic processes. Nearly $25 \%$ of our respondents allow themselves to see that the company's compliance with the law and procedures, i.e. ethical conduct, may harm the company's interests. There is a significant belief that in Polish companies ( $42 \%$ of the surveyed persons), there is no properly strong anticorruption policy or employees do not have information or knowledge about it.

However, the study, the study on the undesirable phenomenon of corruption, shows very clearly that in the long run, such a situation is highly inappropriate and sooner or later comes to light (Witalis 2019).

Generally speaking, when generalising the issues related to corruption in companies, it should be noted that on the one hand there is great human pressure to build correct interpersonal relations in the workplace, which manifest themselves in respect for each individual and respect for his or her rights. This natural and desirable trend is often contradicted by the observation of everyday life and the activities carried out in economic organizations, where we often encounter cases of increased levels and forms of corruption. The painfulness of this undesirable phenomenon results primarily from the fact that in the awareness of employees a sense of senselessness of observing ethical norms is born, the disappearance of mutual trust, the lowering of standards of work ethics, the ennoblement of those who are more responsive, promotions and careers of those who deserve it most are blocked. A group of smarter, unscrupulous employees emerges, which rises to the top in promotions, while the gifted and the better are blocked as part of professional development. Corrupt behaviour on the ground of the company results in a growing conviction that honesty in the workplace is an empty word. Corrupt relations within the working environment:

"[...] transform interpersonal relationships into purely factual ones, where kindness and justice are replaced by egoism, socalled cold calculation and lack of moral scruples. In a corrupt attitude two forms of action are seen: an attempt to buy another person and a readiness to sell oneself. As a result, a person can sell his honesty, convictions, good name, etc., and does so at the price of making a so-called career, earning money, and ensuring so-called material peace. But there is always some contempt for oneself and for other people" (Wziątek - Staśko 2016, p. 65; Zabielski Białystok, p. 28-29; Jarosz 2004, Dylus, Rudowska, Zabrocki 2006, p. 107-120; Makowski 2008).

The emergence of corrupt situations is fostered in Polish conditions by the fact that, according to M. Kosewski, Polish companies are mostly subject-managed, i.e. employees are treated as human resources managed by methods based on behaviourism and the stick and carrot method, i.e. the common use of penalties and rewards. The work performed loses its moral and dignified character, and a staff anomaly sneaks in very intensively, which hinders the formation of the employee ethos and blocks the process of self-control (Kosewski 2012,).

Then, after looking at the negative effects of corruption in a company, we want to notice another unwanted and pathological phenomenon, namely an employee anomy, which is described as an unwritten social contract that allows the employer to be robbed. Employees using this type of conduct often argue that in no case do they go beyond ethical, correct behavior, but take advantage of the opportunity or because of their position. Blikle describes the anomy as:"(...) a very serious disease of the company, consisting in the general agreement of employees on a repertoire of acceptable wickedness that can be compared to sepsis (widespread infection of a biological organism)"(Blikle 2014, p.107).

According to research conducted in Poland in 2012, as many as $78 \%$ of companies suffered significant losses due to unfair behaviour of their employees. For example, a 2008 survey 
found that due to an employee anomy, losses per company were on average about PLN 100,000. Also the surveys carried out in 2011 and 2012 confirm the fact that the phenomenon of anomy is common (Wziątek - Staśko 2016, p. 67; May 2012, p. 7; B. Celmer 2013, p. 133-154) because it was to affect about $77 \%$ of companies. The employee anomy, according to the research conducted in this area, has its psychological background, additionally supported by certain circumstances. Theft occurs as a result of creating opportunities, exposure to human temptation. The phenomenon of employee theft often occurs, as the following psychological mechanisms take place. First of all, there is the process of rationalization, i.e. the emerging process of translation: "the employer will not suffer a loss anyway"; secondly, a process of justification is revealed, consisting of agreeing, already at the group level, what can be stolen and in what quantities. The procedure of anomy develops very easily, starting with small things and ending with serious, in this respect, things of misconduct (May 2012, p.7).

Psychology gives us another important explanation for this procedure. In order to continue to be convinced of one's honesty, while at the same time making a deliberate theft, there must be a prior mechanism of the social process of justifying such acts. An effective excuse for this theft is agreed upon in the group participating in the employee anomy. Typical excuses in this situation are: flattering comparisons, moral credit, lack of victim, condemnation of the victim, denial of responsibility, manipulation of norms (Wziątek - Staśko 2016, p.68-69).

So we see what a wide range of excuses an employee has for his or her reprehensible actions. Trying to determine who the perpetrators of the employee's anomy are, A. Wziątek - Staśko states:"[...] it turns out that thefts are most often committed by employees between the ages of 26 and $40(60 \%$ of all embezzlements), $90 \%$ of them are men, whose statistical working time is $4-10$ years (over $50 \%$ of all embezzlements). In $59 \%$ of these are serial employees. In an anonymous survey conducted by Euler Hermes, as many as $50 \%$ of the employees surveyed admitted that they are appropriating the property of the company they work for". (Wziątek - Staśko 2016, p. 69). Of course, various actions are taken by employers to eliminate this unfavorable fact employee training, investments in security equipment, anti-theft clips, security staff, video surveillance systems, raising salaries for work, dismissing, for example, employees, replacement of employees, increasing control, etc.), but so far there are no significant effects (Staśko 2016, p. 6970).

Trying to sum up this trend of theft within the framework of labour relations, we notice that an employee anomy has an extremely destructive impact on the organization of work of individual employees, disturbs employee and interpersonal relations, causes various psychological complications, shapes an unfavourable image of the organizational culture of economic entities.

The loss of the employees' conviction about the ethics of our company results in another attitude, so undesirable in workplaces, that is the attitude of cynicism. It can be described as a significant drop in employees' confidence in the company's management, as well as in themselves. Employees are beginning to feel comfortable with safety, economic security, well-being, they are afraid that they are losing the opportunity to participate in profits, in the economic success of the company. Gradually, the phenomenon of frustration, disappointment and injustice is growing. According to cynical employees, managers are moving away from the principles of honesty, sincerity towards their staff, and shifting their actions to increase profits for themselves with unclear motives. An employee with a cynical attitude loses hope of improving his own state of affairs with regard to various things, does not believe in the authenticity of his professional career, does not have such an important role in labour relations, a sense of causality, and a process of withdrawal, passivity is born in him:

"The cynical attitude has been recognised as the forerunner of a lack of commitment to work, a decrease in motivation to work, an increase in apathy felt by employees, resignation, lack of hope and even suspicion, contempt and disregard for others" ("Wziątek - Staśko 2016, p. 71).

Another dangerous tendency, which appears in a cynical attitude, is the growth of a feeling of low self-esteem, employees with this attitude are subject to numerous harassment from their superiors, and suffer numerous undesirable social consequences, including health consequences. Among other dangerous tendencies, which make the claim about the occurrence of kitsch in economic and business aspects, there is the problem of bullying or bullying in workplaces. However, there is a certain paradox in this issue, at least when it comes to the Polish reality. Here are the data from the Ministry of Justice, for several years now, more or less a constant number of mobbing cases (700 - data for the years 2007-2014), while the data - even from 2014 - published by the CBOS, report a much more serious number of such offences against employees (Omyła-Rudzka 2014). The revealed discrepancy between the results of research on the issue of mobbing between the data of the Ministry of Justice and the studies carried out by the CBOS gives rise to concern that such pathological behaviours may be, as it is commonly said, swept under the carpet. However, it is more likely that the failure to report these unwanted phenomena in workplaces is the result of ordinary human fear, perhaps also a lack of adequate knowledge among workers. At this point in our argument, we recall, if only briefly, a list of harassment in workplaces developed by Swedish doctor H. Leymann. By examining this pathological behaviour on the basis of employee situations and workplaces, he has compiled a list of 45 behaviours that meet the criteria of bullying. He has put these behaviors into five categories, such as:

"(...)activities affecting the communication processes at the workplace, activities affecting social relations at the workplace, activities affecting the negative perception of the person in the working environment, activities affecting the quality of the professional and personal situation of the victim, activities affecting the victim's health (Wziątek - Staśko 2016, p. 74-75).

There is a need to shape, in business entities, such correct employee foundations which will allow for skilful diagnosing of behaviours that do not comply with legal regulations and create an attitude of readiness to fight against them among 
employees. In the literature on the subject we will find a lot of convincing evidence of significant harmfulness of mobbing phenomena practiced in relation to employees. Clearly, in the case of the occurrence of the phenomenon of mobbing in the organization of work, the phenomenon of worsening of the atmosphere at work, disturbances in interpersonal relations, decrease in productivity and quality of work, loss of trust in the company, increased sickness absenteeism, employee fluctuation, costs of litigation, deterioration of the company's image (Miedzik, p. 42; Bechowska-Gebhardt, Stalewski 2004; Gamian Wilk 2018; Marciniak 2015). Negative behaviour in the work environment is to some extent similar to bullying: discrimination and sexual harassment.

Looking at the phenomenon of discrimination, we notice that its main feature is the unequal treatment of employees in numerous matters related to the employment relationship, and thus include issues of employment, termination of the employment relationship, determination of working conditions, promotion, raising professional qualifications, age, disability, political beliefs, membership of trade unions, etc. In the literature we encounter two forms of discrimination: direct and indirect (Dobrowolska 2013, p. 173-187).

One of the most dangerous manifestations of discrimination in the workplace are all kinds of harassment, i.e. such improper behavior, which aims to violate human subjectivity, dignity and create an intimidating, humiliating atmosphere around the person (Marciniak 2011, p. 44.). Especially in relation to the female world, there is a phenomenon of sexual harassment, consisting in touching, making desirable gestures, glances, in dramatic situations it can also take on the character of sexual violence. The above discrimination occurs because of a specific characteristic of a particular person, his/her beliefs, belonging to a given group, gender, etc. In 2013 THINTANK conducted a study which showed that the factor that made it difficult for $34 \%$ of women to make a career difficult for them to fulfil was gender stereotypes, when the same factor in the case of men affected only $8 \%$ of the male workforce (THINKTANK 2019). As the authors of the research on this phenomenon stress, discrimination has a significant impact on the way we perceive ourselves, our own competences. It is also worth noting the worrying form of discrimination, which is social exclusion. Well:

"The effects of intolerance in the work environment have a negative impact on work motivation, productivity, limit the development of skills, and consequently prevent the effective operation of the company. However, they can also cause health problems, frustration, stress, depression, which is why such forms of discrimination should be opposed in the workplace".(Wziątek - Staśko 2016, p. 80, Kozak, 2009).

A positive trend, however, is the growing trend among companies to counteract any discrimination that occurs, by introducing a strategy of so-called diversity management.

Other pathologies that we would like to mention here are: dysfunctional inter-domain transfer, consisting in uncritical imitation of principles that apply in other industries, organizations, the so-called organizational attention deficit syndrome, which boils down to organizational chaos, the disappearance of responsibility syndrome, authorization of indicators, group decision-making syndrome (Kežun 1998, p. 375-376).

Nowadays, a very significant and dangerous pathology is the growing phenomenon of workaholism. This undesirable phenomenon has a great influence on the functioning of a person, his/her family, co-workers and organization. The phenomenon of workaholism is currently undergoing extensive clinical research, which has made it possible to select several types of workaholics:

- a workaholic who is adamant - he works constantly because he wants to fill all the jobs ahead of time, fearing otherwise he will lose his job,

- a bulimic workaholic - he postpones his work and then throws himself into it, working day and night, without a moment's interruption,

- a workaholic with a lack of attention - seeking impressions, acting without a clear plan. who doesn't pay much attention to deadlines, who starts work and then leaves it and starts new activities,

- a workaholic enjoying work - a very meticulous person who wants to do everything perfectly and is still uncertain whether something needs to be done yet. It is difficult for her to complete a given task,

- a workaholic caring - a person taking on everything, socially engaged, thinks little of himself (Wojdylo 2010).

Dependence on work is growing gradually, although it is becoming more and more difficult to control yourself in this direction with each step. In this process of dependence on work, three periods stand out: initial, critical and chronic (Wziątek Staśko 2016, pp. 82-85).

Of course, this worrying tendency, or even pathology in the workplace, can be signalled here very briefly.

\section{CONCLUSION}

In this article author have mentioned only some of the pathological phenomena that we believe should be of great concern and the desire to eliminate them from economic life, from labour relations. We have signalled far-reaching disturbing consequences for employees at workstations, the level of their dissatisfaction and a decrease in motivation to work when pathologies occur. How often as a result of the loss of positive motivation to work, emotional exhaustion, irritability, pessimism, psychophysical tension appear. As a result of these symptoms a person moves away from other employees, interpersonal contacts become superficial, full of indifference. The emerging stress affects the activities of the entire organization, translating into measurable unnecessary costs in the activities of business entities. Of course, an important question also arises: Who is, in fact, responsible for creating toxic workplaces? However, in our opinion, an attempt to answer such a question requires a separate, broader study. 


\section{REFERENCES}

Beylin P.(1985), Autentyki i kicze. Artykuły i felietony, Warszawa:, p. 180.

Bechowska- Gebhardt A., Stalewski T.(2004), Mobbing - patologia zarządzania personelem, Warszawa.

Blikle A. J.(2014), Doktryna jakości. Rzecz o skutecznym zarządzaniu, Gliwice.

Celmer B.(2013), Dewiacja i anomia w ujęciu systemowym, [w:] Kultura i Społeczeństwo, nr 2,pp. 133-154.

Dobrowolska M.(2013), Postrzeganie zachowań nieetycznych przez pracowników zatrudnionych $\mathrm{w}$ nieatrakcyjnych formach zatrudnienia, [w:], Chudzicka - Czupała A. (red.), Człowiek wobec wartości etycznych i praktyka, Prace Naukowe UŚ, Katowice, nr 3013, pp. 173-187.

Dylus A. , Rudowska A., Zabrocki M., Makowski G.(2008), Korupcja jako problem społeczny, Warszawa.

Dylus A.(2006), Kulturowe uwarunkowania korupcji. Doświadczenie Polski, [w:] Dylus A., Rudowski A., Zaborski M., (red. naukowa), Korupcja. Oblicza, uwarunkowania, przeciwdziałania, Warszawa -Wrocław, pp. 107-120.

Gamian Wilk M.(2018), Mobbing w miejscu pracy: uwarunkowania i konsekwencje bycia poddanym mobbingowi, Warszawa.

Grudzewski W. M., Hejduk I. K., Wańtuchowicz M.(2009), Zarządzanie zaufaniem w przedsiębiorstwie. Koncepcja, narzędzia, zastosowania, Kraków.

Jarosz M.(2004), Władza, przywileje, Korupcja, Warszawa.

Johnston M.(2008), Fighting Systematic Corruption: Social Foundations for Institutional reform, w: European Juornal of Development RFesearch, t. 10, nr 1 (wyd. spec.), p.89, cyt. za: Makowski G. , Korupcja jako problem społeczny, Warszawa,s. 17, [in:]: http://isws.ms.gov.pl/baza-statystyczna/opracowaniawieloletnie/.

http://synonim.net/synonim /kicz,

http:/swiat.newsweek.pl/globalny-raport-transparency-international-korupcjanewsweek-pl.artykuły,352917,1.html,

Kieżun W.(1998), Sprawne zarządzanie organizacją. Zarys teorii i praktyki, Warszawa

Kosewski M.(2012), Triada współzależności: jakość-samokontrola-etos pracowniczy, [in:] Anomia pracownicza w Polsce raport oszustw i kradzieży w firmach, p.15.

Kozak S.(2009), Patologie w środowisku pracy. Zapobieganie i leczenie, Warszawa.

Kudra B., Szkudlarek - Śmiechowicz E.(2016), Kicz w języku i komunikacji, Łódź, p.9.

Macko M.(2009), Poczucie sprawiedliwości organizacyjnej a zachowania pracowników, Poznań,p. 9.

Maj M.(2012), Czym jest anomia pracownicza?, [w:] Anomia pracownicza w Polsce 2012, Raport oszust i kradzieży w firmach ,Euler Hermes - Work Service.

Makowski G.(2008), Korupcja jako problem społeczny, Warszawa.

Marciniak J.(2011), Mobbing, dyskryminacja, molestowanie - zasady przeciwdziałania, Warszawa.

Marciniak J.(2015), Mobbing, dyskryminacja: przeciwdziałanie w praktyce, Warszawa.

Miedzik M.(2010), Skutki mobbingu w miejscu pracy; dramat człowieka, koszty dla organizacji, wyzwania dla społeczeństwa, [in:] Zarządzanie Zasobami Ludzkimi, nr 2, p. 42.

Mierzwiński M.(2002), Korupcja jako problem społeczno-moralny w polskiej literaturze przedmiotu okresu posoborowego, Warszawa.

Omyła-Rudzka M.(2016), Komunikat badań CBOS: Szykany w miejscu pracy, Warszawa , lipiec 2014, cyt. at: Wziątek - Staśko A., Motywowanie w erze WEB $2.0+$, Warszawa, pp. 72-73.
Piątkowski K.(2008), Kicz jako problem antropologiczny, [in:], Burszta W. J., Sekuła E., Sekuła, A., Kiczosfery współczesności, Warszaw, pp. 12-13.

THINKTANK - analiza: Raport projektu „Kobieta aktywna” realizowanego przez członków Klubu Dyrektora personalnego,

Witalis M., [in:] Raport-EX -zdaniem-43-polskich-respondentów-korupcja-wbiznesie-to-zjawisko-powszechne,

Wojdyło K.(2010), Pracoholizm. Perspektywa poznawcza, Warszawa.

Wziątek - Staśko A.(2016), Motywowanie w erze WEB 2.0 +, Warszawa: Dinfin.

Zabielski J.(2004), Fenomen współczesnej korupcji i jej etyczna ocena, Białystok.

Żuchowska G.(2013), Kicz- przegląd koncepcji teoretycznych i propozycja definicji do celów badawczych, [in:] Kultura i Społeczeństwo, nr 1, pp. 131151 . 